\title{
Hyponatraemia: Nadirs and Paradoxes of the Missing Volumetric Overload
}

\author{
Ahmed N Ghanem* \\ Consultant Urologist Surgeon, Egypt \\ Received: November 22, 2018; Published: December 13, 2018 \\ *Corresponding author: Ahmed N Ghanem, Consultant Urologist Surgeon, No1 President Mubarak Street, Mansoura 35511, Egypt
}

\section{Short Communication}

Hyponatraemia (HN) affects adults and children [1]. The authors concluded that: "acute hospital induced hyponatraemia is caused by electrolyte-free fluids, or 'volumetric overload type1 (V01)', in the presence of elevated vasopressin. The condition affects men, women and children, particularly postoperative patients. It is responsible for far greater morbidity and mortality than generally received." It concerns not only physicians and intensive care therapists among all clinicians who prescribe fluid therapy in the most compelling of clinical emergencies, but also primarily surgeons.

The authors' call for a change of the policies on fluid therapy is fully supported but requires scientific justification. It is interesting that such revolutionary conclusion is based on a retrospective study and observations. Had I been gifted with the clarity and authority with which the conclusion was given, not only HN but also the puzzle of the multiple vital organ dysfunction/ failure (MVOD/F) syndrome or acute respiratory distress syndrome (ARDS) should have been resolved long ago. I commend the Editor and reviewers of BMJ for considering this study an evidencebased medicine.

I have long recognized these conditions as killers of surgical patients and have spent most of my career life investigating and understanding. My initial observations were communicated over 32 years ago [2]. For resolving giant clinical puzzles such as HN and MVOD/F, one needed to fly high for a bird's eye view and dive deep for a close-up examination of a piece of evidence that lies at the bottom of the ocean of knowledge on the subject. In doing so, artificial boundaries of science and super specialties of medicine and surgery needed crossing for gathering the scattered pieces of evidence. Missing pieces were either excavated and rejuvenated or newly discovered. Facts needed segregation from fallacies, and reorganization, in order to reconstruct the real picture.

Although acute HN is 'iatrogenic complication' of fluid therapy, it should not cause any 'guilt feeling'. It is a complex problem with wide range of severity and many masks of presentations. It underlies many variously named but identical clinical syndromes such as the transurethral resection of the prostate (TURP) syndrome and others affecting medical and surgical patients [2].
It may be confused with many recognized medical conditions as well as features of MVOD/F [3]. Its primary nadir and paradox remain overlooked. The key for resolving the puzzles relates to a century old erroneous physiological law that dictated the 'faulty rules' on fluid therapy [4]. The authors alluded to the 'missing' V01 at the second nadir of HN on tertiary referral. This article's main objective is to identify, locate and quantify the 'missing' V01 and uncover its primary nadir and paradox. Major surgery in general and TURP are examples where and when V01 may induce the condition and its first nadir [5]. Not only the faulty rules on fluid therapy dictate the infusion of large VO during surgery but also, Invariably and incorrectly, every hypotension episode is considered synonymous with hypovolaemia [3].

The observed paradox was this: V01 of about $5 \%$ body weight (BW) gained in one hour may cause hypotension shock. This misleadingly calls for further vascular expansion using electrolytebased fluids (VO2), inducing shock, coma and acute renal failure (ARF) among other features of the MVOD/F syndrome.

Dilutional hyponatraemic shock was reported 55 years ago [6] and later in patients suffering from the TURP syndrome [7]. It represents V01 vascular shock. Our prospective study [5] precisely quantified V01 by adding the per-operative infused fluids to the measured volume of absorbed $1.5 \%$ Glycine irrigant. After providing anecdotal evidence [8], our prospective study also re-juvinated the life-saving therapy of instant rapid infusion of hypertonic sodium therapy (HST) such as $5 \% \mathrm{NaCl}$ or $8.4 \mathrm{NaCo}_{3}$ [7].

Further experience showed that $8.4 \%$ sodium bicarbonate is a good alternative therapy but lower sodium concentrations of HST are less effective. All VO2 fluids such as isotonic saline is harmful, as it clouds the serum markers while aggravating VO and establishing the MVOD/F syndrome [3-5]. V01 dilutes all serum contents and induces the first nadir of HN [5], manifesting at the immediate post-operative period. The second nadir of HN may appear less seriously later, reflecting much less V01 than was gained. This is due to the intracellular osmotic shift of fluid. Cellular oedema manifests with encephalopathic coma and ARF, among other features of MVOD/F [3,4]. 
Further delay, before and after involving the physicians, may make HN chronic, establishing the permanent brain damage. The latter was incorrectly attributed to HST. The second nadir of HN may also follow another common scenario: any urinary output that represents a recovery from V01, when chased by fluid input may keep the retained V01 constant or increased. No pitting oedema occurs because most of the 'missing' V01 resides inside the cells. Time plays a vital hidden role on the nadirs of HN of V01. This was the hardest to understand and unravel. "VO versus time" (of fluid infusion) is a helpful concept to consider in clinical settings requiring massive fluid therapy or vascular expansion.

Contrasting the physiological effects of a normal daily fluid intake (about $5 \% \mathrm{BW}$ or $3.5 \mathrm{l}$ of $70 \mathrm{Kg}$ ) to its pathological effects when infused in one hour, should be considered very seriously. Mathematical calculation reveals that such VO1 lowers the serum sodium from 140 to $112 \mathrm{mmol} / \mathrm{l}$ (the first HN nadir). Assuming no further input or output occurred, the time (of osmotic equilibrium) might spontaneously elevate the second nadir to $129 \mathrm{mmol} / \mathrm{l}$. This is the result of extracellular fluid space dilution by only $1.2 \mathrm{l}$. The 'missing' $2.3 \mathrm{l}$ of gained V01 resides in cells.

Perhaps, a better approach for resolving such complex clinical problem was to go 'back to basics and to the future': to recognize the error of the physiological law that dictated the faulty rules on fluid therapy. Physical studies, done in 1984 and reported in 2001 [4], discovered a hydrodynamic phenomenon with physiological and clinical relevance to the mentioned conditions. This may provide a tenable alternative hypothesis for the capillary-interstitial fluid transfer, and the scientific basis for the call to change the policies on fluid therapy. Recently I have reported all the evidence to consider volumetric overload shock (VOS) a clinical reality [9-11] and to prove that Starling's law is wrong providing the alternative of hydrodynamics of a porous orifice $(G)$ tube [12].

\section{References}

1. Halberthal M, Halperin ML, Bohn D (2001) Acute hyponatraemia in children admitted to hospital: retrospective analysis of factors contributing to its development and resolution. 322: 780-782.
2. Dandona P, Fonseca V, Baron DN (1985) Hypoalbuminaemic hyponatraemia: a new syndrome? Br Med J 291(6504): 1253-1255.

3. Ghanem AN (2000) Monitoring the critically ill patient. J R Coll Surg Edinb 45(2): 138-139.

4. Ghanem AN (2001) Magnetic field-like fluid circulation of a porous orifice tube and relevance to the capillary-interstitial fluid circulation: Preliminary report. Med Hypotheses 56(3): 325-334.

5. Ghanem AN, Ward JP (1990) Osmotic and metabolic sequelae of volumetric overload in relation to the TURP syndrome. Br J Uro 66: 71-78.

6. Danowski TS, Winkler AW, Elkington JR (1946) The treatment of shock due to salt depression; comparison of isotonic, of hypertonic saline and of isotonic glucose solutions. J Clin Invest 25(1): 130-138.

7. Harrison RH III, Boren JS, Robinson JR (1956) Dilutional hyponatraemic shock: another concept of the transurethral prostatic reaction. J Urol 75(1): 95-110.

8. Ghanem AN, Wojtlewski JA, Penney MD (1987) Dangers in treating hyponatraemia. Br Med J 294(6575): 837.

9. Ghanem AN, Ghanem SA (2016) Volumetric Over load Shocks: Why Is Starling's Law for Capillary Interstitial Fluid Transfer Wrong? The Hydrodynamics of a Porous Orifice Tube as Alternative. Surgical Science 7(6): 245-249.

10. Pindoria N, Ghanem SA, Ghanem KA, Ghanem AN (2017) Volumetric overload shocks in the patho-etiology of the transurethral resection prostatectomy syndrome and acute dilution hyponatraemia. Open Access J Surg 7(5): 1-8.

11. Ghanem KA, Ghanem AN (2017) Volumetric overload shocks in the patho-etiology of the transurethral resection prostatectomy syndrome and acute dilution hyponatraemia: The clinical evidence based on 23 case series. Basic Research Journal of Medicine and Clinical Sciences 6(4) 35-43.

12. Ghanem KA, Ghanem AN (2017) The proof and reasons that Starling's law for the capillary-interstitial fluid transfer is wrong, advancing the hydrodynamics of a porous orifice $(\mathrm{G})$ tube as the real mechanism. Blood, Heart and Circ 1(1): 1-7.

\section{Your next submission with Juniper Publishers will reach you the below assets}

- Quality Editorial service

- Swift Peer Review

- Reprints availability

- E-prints Service

- Manuscript Podcast for convenient understanding

- Global attainment for your research

- Manuscript accessibility in different formats

( Pdf, E-pub, Full Text, Audio)

- Unceasing customer service

Track the below URL for one-step submission https://juniperpublishers.com/online-submission.php 